\title{
NOTES FROM EASTERN ALBERTA.
}

BY WINTHROP S. BROOKS AND STANLEY COBB.

THE following observations were made between August 15, 1909, and February 1, 1910, within a five mile radius of the northern end of Birch Lake, Alberta (latitude $53^{\circ} 20^{\prime \prime}$ N., longitude $111^{\circ} 40^{\prime} \mathrm{W}$.), about 90 miles east of Edmonton, the capital of the province. The altitude here is about 1,800 feet above sea level.

Birch Lake itself is a large body of water, some 20 square miles in area, sending northward a long shallow arm. The country immediately surrounding this northern arm consists of level prairie, the smooth expanse of grass occasionally interspersed with patches of bushes. About a mile and a half north of the lake the topography changes to low, rolling hills, with an increase of the bushy growth and scattered groups of small trees. This area is thickly dotted with shallow sloughs and small lakes of varying sizes; the whole forming an admirable resort for wild fowl and waders.

The waders, however, seemed to leave this region very early. On August 15 when Birch Lake was first visited many varieties of shore birds were seen by hundreds, but on returning on the 19th the numbers were much diminished; thereafter they kept leaving steadily, until by September 1 (when, by the way, the shooting season in Alberta opens on these birds) the great majority had left for the south. Yellowlegs and Pectoral Sandpipers were the only species that remained abundant through September.

The list is obviously limited, but as the observers went into the country purely on a shooting trip, birds other than wild fowl and waders were noted only during spare moments, or when they chanced to be in the writers' paths.

1. Colymbus holbœlli. Holbcll's Grebe.-A few seen Sept. 3 .

2. Colymbus auritus. Horned Grebe.- Several noted.

3. Podilymbus podiceps. Pied-BIlled Grebe.-Quite common.

4. Gavia immer. Loon.-One immature shot, Sept. 15.

5. Larus delawarensis. Ring-BILled Gull.-Fairly common on larger bodies of water. 
6. Larus philadelphia. Bonaparte's Gull- - Abundant in a small lake 3 miles north of Birch Lake, whence they flew to the latter every night. Last seen Oct. 13.

7. Hydrochelidon nigra surinamensis. Black Tern.-Fairly common until the middle of September.

8. Lophodytes cucullatus. Hooded Merganser.- Several seen Aug. 15 and 19.

9. Anas platyrhynchos. Mallard--Breeds here. Abundant, staying until lakes were frozen over.

10. Chaulelasmus streperus. Gadwall.-Breeds. Fairly common until Sept. 11 when a great flight arrived. Left about Oct. 1.

11. Mareca americana. Baldpate.-Abundant. Apparently breeds here. Last noted on Oct. 9.

12. Nettion carolinense. Green-winged Teal-- Abundant in sloughs. Breeds. Last noted Oct. 6 .

13. Querquedula discors. Blue-Winged Teal- - Abundant; breeds. Last noted Oct. 6.

14. Spatula clypeata. Shoveller.-Abundant; breeds. Left the last of September.

15. Dafila acuta. Pintail. - Breeds. Common, but less so than the other Anatinæ. Last noted on Sept. 29.

16. Marila americana. REDHEAD.-Uncommon, seen only on larger bodies of water.

17. Marila valisneria. CANVAS-BACK.-Quite common; breeds.

18. Marila affinis. Lesser Scaup Duck.-Abundant; breeds. Remained until lakes were frozen over.

19. Clangula islandica. Barrow's Golden-Eye.-Common on larger bodies of water during last of September and first part of October. First seen Sept. 10 when 2 females were shot.

20. Charitonetta albeola. Buffle-HEAD.- Fairly common; breeds.

21. Oidemia deglandi. White-WINGed Scoter.-Fairly common; apparently breeds.

22. Erismatura jamaicensis. Ruddy Duck.-A few seen.

23. Chen hyperboreus hyperboreus. SNow Goose.- Three flocks of from 100 to 300 seen on Oct. 11 and 13 .

24. Branta canadensis canadensis. Canada Goose.-Quite common, breeds; very few flight birds seen.

25. Botaurus lentiginosus. Bittern.-- Common about sloughs.

26. Ardea herodias herodias. Great Blue Heron.-One seen on Aug. 22.

27. Grus americana. Whooping Crane. - Several flocks of large cranes were seen flying southward, high in the air, and uttering a mellow, rolling call; one of these flocks contained 57. On the night of Sept. 21 there was a heavy migration of these birds, their call being heard at all hours of the night. Positive identification was impossible, but as the birds were very large, and were migrating from the north, it seems reasonably certain that they were Whooping Cranes. 
28. Porzana carolina. SonA.-Quite common about sloughs.

29. Fulica americana. Coот.-Flocks noted on Birch Lake on Aug. 19 and 23.

30. Steganopus tricolor. Wilson's Phalarope.-Small flocks seen several times on Birch Lake.

31. Recurvirostra americana. Avocet.- Six seen at Birch Lake Aug. 15.

32. Gallinago delicata. Wilson's Snipe.-Abundant. Tremendous flight on Aug. 24.

33. Macrorhamphus griseus griseus. Dowitcher.- On Aug. 19 we fired into a flock of ten Dowitchers killing two of this variety, and one Long-billed Dowitcher.

34. Macrorhamphus griseus scolopaceus. Long-BILled DowITCHER.- Beside the above record one was shot on Aug. 28.

35. Micropalama himantopus. StiLt SANDPIPER.-Three seen on August 28 at Birch Lake, two of which were shot. Another was shot on Sept. 6. All were in company with Yellowlegs.

36. Pisobia maculata. Pectoral Sandpiper.-Common Aug. 28 to Oct. 5 .

37. Pisobia bairdi. BaIRd's SANdPIPER.-Common at Birch Lake.

38. Pisobia minutilla. Least SANDPIPER.-Common at Birch Lake.

39. Ereunetes pusillus. Semipalmated Sandpiper.-Uncommon.

40. Calidris leucophæa. Sanderling.- One shot at Birch Lake, Sept. 6.

41. Limosa fedoa. Marbled Godwit.-Quite common around Birch Lake in flocks of 4 or 5 . Left early in September.

42. Totanus melanoleucus. Greater Yellowlegs.- Uncommon.

43. Totanus flavipes. Yellowlegs.- Very abundant about lakes and sloughs. Last seen on Oct. 5 .

44. Helodromas solitarius cinnamomeus. Western Solitary SANDPIPER.- Common.

45. Catoptrophorus semipalmatus inornatus. Western Willet. - Six seen in all; on Aug. 15 and 19, and Sept. 2.

46. Bartramia longicauda. Upland Plover.-Two seen on Aug. 15.

47. Tryngites subruficollis. Buff-Breasted Sandpiper.-A few seen at Birch Lake during latter part of August. Two specimens taken.

48. Actitis macularia. Spotted Sandpiper.- Several noted between August 15 and 30 at Birch Lake.

49. Squatarola squatarola. Black-Bellied Plover.- Common on the Birch Lake flats.

50. Charadrius dominicus dominicus. Golden Plover.- A few shot during latter part of August.

51. Oxyechus vociferus. Killdeer.- Not an abundant bird, but a few could always be found.

52. \#gialitis semipalmata. Semipalmated Plover.-Common at Birch Lake in August. 
53. Arenaria interpres morinella. Ruddy Turnstone.-Twice noted at Birch Lake; one seen on Aug. 25; two seen, one shot, on Aug. 28.

54. Bonasa umbellus umbelloides. Gray Ruffed Grouse.A few small flocks were seen in late autumn in the low growth about lakes.

55. Pediœcetes phasianellus campestris. Prairie Sharp-tailed Grouse.- Abundant in small coveys until about Nov. 1, when those in the vicinity formed into two large flocks of from 75 to 100 each.

56. Cathartes aura septentrionalis. Turkey Vulture.-One seen flying over prairie Sept. 7 .

57. Circus hudsonius. Marsh Hawk.-Very common. Twice found eating ducks we had shot.

58. Buteo borealis calurus. Western Red-tail.-One seen Aug. 24.

59. Buteo swainsoni. Swainson's HAwk.- This bird and the Marsh Hawk were the typical hawks of the region. Every landscape seemed to contain a Marsh Hawk flapping low over the prairie and a stolid Swainson's sitting on some fence post or hay stack.

60. Aquila chrysaëtos. Golden Eagle.-Two seen late in October.

61. Falco columbarius columbarius. Pigeon Hawk.-A few seen in September.

62. Falco sparverius. Sparrow Hawk.-- Several seen on Aúg. 19.

63. Pandion haliaëtus carolinensis. Osprey.-One flying over Birch Lake on Sept. 17.

64. Asio flammeus. Short-eared Owl.-Abundant. Could be found around nearly every slough at twilight.

65. Bubo virginianus pallescens. Western Horned OWL.- One seen Oct. 11. Two found poisoned by coyote baits on Nov. 17.

66. Dryobates villosus leucomelas. Northern HaIry WoodPECKER.- One seen Nov. 15.

67. Colaptes auratus luteus. Northern Flicker.-Two noted Sept. 15.

68. Tyrannus tyrannus. KIngBIRD.- Common.

69. Corvus corax principalis. Northern Raven.- One seen every day during week of Nov. 15 to 22 .

70. Corvus brachyrhynchos brachyrhynchos. Crow.-Abundant; often in tremendous flocks.

71. Sturnella neglecta. Western Meadowlark.- A few noted.

72. Icterus spurius. Orchard Oriole.- One seen Aug. 19.

73. Euphagus cyanocephalus. Brewer's BlackBIRD.- Abundant; left about Sept. 20.

74. Astragalinus tristis. GoldFinch.-A few noted during latter part of August.

75. Plectrophenax nivalis nivalis. Snow Bunting.- Appeared the first week in November. Abundant.

76. Calcarius lapponicus lapponicus. LAPLAND LONGSPUR.Abundant in large flocks during latter part of September. 
77. Poœcetes gramineus confinis. Western Vesper Sparrow.-A few seen in August.

78. Passerculus sandwichensis alaudinus. Western Savannah Sparrow.- Common on prairie.

79. Ammodramus savannarum bimaculatus. Western GrassHOPPER SPARROW.- Quite common in long grass.

80. Zonotrichia leucophrys leucophrys. White-crowned SparRow.- Several seen Sept. 5 .

81. Spizella monticola ochracea. Western Tree Sparrow.Common during first part of October.

82. Progne subis subis. Purple Martin.-Quite a number seen flying over Birch Lake on Aug. 25.

83. Iridoprocne bicolor. Tree Swallow.- A large number seen with the Purple Martins on Aug. 25.

84. Bombycilla cedorum. Cedar Waxwing.-Three observed Aug. 30 .

85. Lanius borealis. Northern Shrike.-Two seen Oct. 5.

86. Anthus spraguei. Sprague's Pipit.-Abundant.

87. Penthestes atricapillus septentrionalis. Long-tailed CHickADEE.- First seen Oct. 4; common for a few days after this.

88. Planesticus migratorius propinquus. Western RoBin.Two seen Aug. 30.

\section{A NOTE ON THE NESTING OF THE WHIP-POOR-WILL.}

BY A. DAWES DU BOIS.

THE following notes were made in connection with two nests of the Whip-poor-will (Antrostomus vociferus) near the village of Bradford, in Sangamon County, Illinois. The first nest was found on May 16, 1908, in a strip of woods of medium size trees, thickly undergrown, on a high bank of the Sangamon River. The ground was well carpeted with dried oak leaves. Our first intimation of Whip-poor-wills in this place was the sudden appearance of an adult bird fluttering along the ground in front of us, apparently with a broken wing. We stopped at once and while my companion stood to mark the place, I followed the bird a short distance. She fluttered along noiselessly, feigning serious 


\section{$2 \mathrm{BHL}$ Biodiversity Heritage Library}

Cobb, Stanley. 1911. "Notes from Eastern Alberta." The Auk 28, 465-469. https://doi.org/10.2307/4071165.

View This Item Online: https://www.biodiversitylibrary.org/item/54988

DOI: https://doi.org/10.2307/4071165

Permalink: https://www.biodiversitylibrary.org/partpdf/87491

\section{Holding Institution}

Smithsonian Libraries

\section{Sponsored by}

Smithsonian

\section{Copyright \& Reuse}

Copyright Status: Public domain. The BHL considers that this work is no longer under copyright protection.

This document was created from content at the Biodiversity Heritage Library, the world's largest open access digital library for biodiversity literature and archives. Visit BHL at https://www.biodiversitylibrary.org. 